Reprod. Nutr. Dévelop., 1981, 21 (4), 531-544.

\title{
Modes of intestinal cholesterol absorption in adult sows
}

\author{
par Jocelyne AIGUEPERSE ***, J. REMY**, F. CHEVALLIER * \\ * Laboratoire de Physiologie de la Nutrition (1), Bât. 447 \\ Université Paris-Sud, 91405 Orsay Cedex, France. \\ ** Laboratoire de Radiobiologie appliquée, Département de Protection, \\ Commissariat à l'Energie atomique, 78350 jouy en Josas, France.
}

\begin{abstract}
Summary. The nature and distribution of neutral sterols has been determined in the digestive tract of adult Large White sows maintained in a defined biological steady state (constant weight : $70+5 \mathrm{~kg}$ ). The semi-synthetic diet contained $0.08 \mathrm{p}$. 100 cholesterol. Cholesterol was the main sterol of the intestinal contents. From the caecum, it was partially transformed into coprostanol ( $<6 \mathrm{p}$. 100). Just before the morning meal, the intestinal contents of the sows were rich in cholesterol (532 $\mathrm{mg}$ in the small intestine). As in rats, this rapidly renewed cholesterol of endogenous origin was not distributed homogeneously with the exogenous dietary cholesterol. During intestinal cholesterol transit, hydrolysis exceeded esterification.

Using the principle of occupancy of every dynamic system, two isotopes were employed to measure the absorption coefficient : cholesterol-4-14 $\mathrm{C}(10 \mu \mathrm{Ci})$, incorporated into the meal and ingested at one time, and cholesterol- ${ }^{3} \mathrm{H}(400 \mu \mathrm{Ci})$, injected intravenously once in a suspension of autologous red blood cells previously labelled in vitro. The absorption coefficient of dietary cholesterol in our experimental conditions reached $57 \pm 4$ p. 100. The cholesterol was mainly absorbed in the first-half of the small intestine as in man, whereas in rat it is absorbed in the second-half. This dietary tracer appeared in the general circulation later in swine than in rat or man. After intake of a meal containing the cholesteral tracer, maximal plasma cholesterol radioactivity was reached after 48 hrs in the sows while it is reached after 10-12 hrs in rat or man.
\end{abstract}

\section{Introduction.}

It is surprising that after Yorkshire or miniature swine are given a single intake of labelled cholesterol in the meal (Kim ef al., 1974, 1975) or an injection of labelled cholesterol directly into the duodenal lumen (Dupont ef al., 1974), the specific activity of the plasma cholesterol tracer is maximal 2, or even 3, days after it is introduced, whereas in man and rat, only 10 to $12 \mathrm{hrs}$ are needed to attain a maximum. It may thus be inferred that dietary cholesterol absorption processes are slower in swine than in man or rat.

(1) Equipe de Recherche Associée au CNRS (ERA 0415). Formation de Recherche Associée d̀ I'INSERM (FRA 41). 
As part of a more general study of the rates of cholesterol renewal processes in swine, the present work analyze the results obtained after a single intake of cholesterol-4-14 $\mathrm{C}$ incorporated into a meal. By comparing adult Large White sows, kept in standard experimental conditions, to man and rat, we defined those characteristics of the intestinal absorption process which are specific to swine.

\section{Material and methods.}

Animals and diet. - At weaning, 10 adult Large White sows received a solid commercial diet (No. 307, La Minière, INRA) consisting of 74 p. 100 barley, 4 p. 100 peanut oil cake, 4 p. 100 soybean oil cake, 3 p. 100 alfalfa meal, 4 p. 100 fish meal, 4 p. 100 yeast, 4 p. 100 vitamin mixture, 3 p. 100 mineral supplement. At the age of 7 months, the animals weighed $70 \pm 5 \mathrm{~kg}$. They were placed in separate cages $(1: 134 \mathrm{~cm}$; $w: 82 \mathrm{~cm} ; \mathrm{h}: 107 \mathrm{~cm})$ under artificial or neon lighting : $9 \mathrm{hrs}$ of light $(8 \mathrm{a} . \mathrm{m}$. to 5 p.m.) to 15 hrs of darkness, and were given a different diet (convalescent No. 2, La Minière, INRA) consisting of 34 p. 100 skim milk, 48 p. 100 starch, 4 p. 100 cellulose, 6 p. 100 lard, 2 p. 100 vitamin mixture, 6 p. 100 mineral supplement. Half ot this semipurified diet, containing 6 p. 100 lipid (lard) and 0.08 p. 100 cholesterol, was distributed at 8:30 a.m. and half at 4:30 p.m. (Aigueperse et al., 1978). The phytosterol content was negligible. This pre-experimental period lasted 10 to 12 weeks.

Since we needed to work with biological material in a steady state, the weight of the animals was kept constant ( \pm 4 p. 100) during the preexperimental and experimental periods by restricting the daily energy ration to $3500 \mathrm{kcal}$, which corresponded to an intake of $1 \mathrm{~kg}$ of the semi-purified diet. Water was supplied ad libitum.

Experimental procedure. - Cholesterol-4- ${ }^{14} \mathrm{C}$ (specific activity : $40-50 \mathrm{mCi} / \mathrm{mM}$; CEA) was incorporated, at a rate of $10 \mu \mathrm{Ci} / 500 \mathrm{~g}$, into the semi-purified diet previously wetted with ethyl-ether. At 9 a.m. on experimental day 1 , each animal ingested $500 \mathrm{~g}$ of this labelled diet at one time and in less than $10 \mathrm{~min}$.

Daily blood sampling $(30 \mathrm{ml})$ was facilitated by placing a catheter in the jugular vein 2 days before the experiment started. The heparinized blood was centrifuged $\left(2200 \times \mathrm{g}, 4^{\circ} \mathrm{C}, 10 \mathrm{~min}\right.$ ), the plasma separated from the red cells, and both fractions stored in ethanol. Each morning the stools were collected, weighed and homogenized with $200 \mathrm{ml}$ of water in a Sorvall apparatus. Two aliquot specimens were preserved in ethanol for chemical analysis.

The sows were sacrificed by intracardiac puncture in lots of two, $1 \mathrm{hr}$ (sows no. 1 and 2), 6 hrs (sows no. 3 and 4), 2 days (sows no. 5 and 6), 4 days (sows no. 7 and 8) and 33 days (sows no. 9 and 10) after ingesting the labelled meal. They were first anesthetized with fluothane-dinitrogen monoxide + pentothal for blood sampling $(30 \mathrm{ml})$. At sacrifice, the cardiovascular system was washed by ear perfusion with 2 liters of isotonic saline solution.

The abdomen was opened, and earch part of the digestive tract (stomach, small intestine, cecum, colon, rectum) was taken after isolation in situ by a ligature at each end. The small intestine was divided in situ into four parts : duodenum, proximal jejunum, distal jejunum and ileum, and its end were ligated at the level of the pylorus and 
Bauhin's valve. A double ligature was made at the following reference points ; Treitz's angle for the distal extremity of the jejunum and the mesocecum insertion for the proximal extremity of the jejunum. A final double ligature was performed so that the two jejunal segments would be approximately equal.

Each isolated segment of the digestive tract was freed of the remaining mesentery, and its contents washed with a 0.9 p. 100 saline solution; the walls and contents of these different segments were then weighed and preserved in ethanol.

To determine the cholesterol absorption coefficient, it is necessary to simultaneously administer labelled cholesterol orally and intravenously. A colloidal suspension of labelled cholesterol may be injected by intravenous route (Zilversmit, 1972). But, in this study, we based our method on plasma results obtained in another experiment with 4 sows (Aigueperse et al., 1981a) which were intravenously injected $(400 \mu \mathrm{Ci})$ with an autologous red blood cell suspension previously labelled in vitro with tritiated cholesterol (Aigueperse and Chevallier, 1981b). As this is a colloidal suspension of the cholesterol tracer, the plasma cholesterol could be labelled by an exchange of free cholesterol between the red cells and the plasma.

Chemical analysis. - The lipid was extracted for $48 \mathrm{hrs}$ in boiling ethanol. The total neutral sterols of the intestinal contents and stools were then obtained by saponification of the lipid extracts (boiling ethanol, $2 \mathrm{~N} \mathrm{KOH}, 3 \mathrm{hrs}$ ) and petroleum ether extracfion, followed by digitonin hot precipitation (Caminade, 1922).

The sterols of the intestinal contents were qualitatively analyzed for the nonsaponifiable fraction (neutral sterols) of the lipid extract, and also for the digitonin complex broken down by pyridine ( 1 assay per isolated digestive contents) (Schoenheimer and Dam, 1953). The operating conditions for this analysis, carried out in gasliquid chromatography (GLC), have been described previously (Aigueperse ef al., 1978). In order to define the nature of intestinal sterols other than cholesterol and coprostanol, thin-layer chromatography separations were effected, first on silicic acid (Carl Schliecher and Schüll) and then on alumina impregnated with silver nitrate. In the first case, a solvent mixture (hexane-diethylacelate ; 8/2) was used and the sterols were separated according to their polarity; in the second case, the solvent system included chloroform, hexane and acetone (60/30/3) and the sterols were separated according to their degree of non-saturation (Kammereck et al., 1967).

The free and esterified cholesterol of the plasma and intestinal walls, isolated by silicic acid column chromatography (Chevallier and Mathé, 1964), were assayed by the Lieberman-Burchard reaction after digitonin cold precipitation.

The activities were measured in PPO-dimethyl POPOP-toluene solution using a liquid scintillation spectrometer (Interfechnique) with an external standard for quenching correction.

Determination of the absorption coefficient. - As the cholesterol of an organism constitutes a dynamic system of clearly defined structure, the absorption coefficient could be determined by the occupancy principle (Bergner, 1964 ; Chevallier, 1972 ; Orr and Gillespie, 1968). This principle can only be applied if the system is in equilibrium, which was indeed the case with our animals as they were maintained at a constant weight. The method using the occupancy principle requires two simultaneous experiments with different isotopes in the same animal. The first experiment consists of a 
single intake of labelled cholesterol (for example, cholesterol-4-14 $\mathrm{C}$ ) of $\mathrm{q}(\mathrm{I})$ activity incorporated into the meal. The specific activity, $a(l)$, of the plasma tracer is measured for several weeks. The second experiment uses a single intravenous injection of labelled cholesterol (for example, cholesterol- ${ }^{3} \mathrm{H}$ ) of $q(x)$ activity. The specific activity, $a(x)$, of the plasma tracer is measured during the same period. In the present study, the latter experiment used 4 different animals which were prepared in exactly the same way as those of the first experiment. They received a single intravenous injection of a suspension of autologous red blood cells previously labelled in vitro with cholesterol- ${ }^{3} \mathrm{H}$ (Aigueperse ef al., 1981b).

Under these conditions, the absorption coefficient $(K)$, defined as the ratio between the absorption flow (A) and the intake flow (I), was determined by the following equation :

$$
K=\frac{A}{l}=\frac{\frac{\int_{0}^{\infty} a(I)}{\int_{0}^{\infty} a(x)}}{\frac{q(x)}{\int_{(I)}}}
$$

The method of Zilversmit (1972), defining the plasma isotope ratio, $a(I) / a(x)$, is derived from that described above and gives a good approximation of the cholesterol absorption coefficient (Aigueperse, 1980).

\section{Results.}

Qualitative and quantitative analysis of sterols in the contents and walls of the digestive tract. - Cholesterol was the only sterol detected in the stomach and the small intestine together with traces $(<1$ p. 100) of unidentified sterols in the contents of the proximal jejunum. Moreover, from the cecum to the rectum, the intestinal contents showed a common chromatogram ; the following sterols were identified in the order in which they left the column : coprostanol, cholesterol, c group of phytosterols with reduced $5 \beta$ and dihydrolanosterol, then a mixture of unsaturated phytosterols in position 5-6 (such as cholesterol), and finally a small quantity of sterols which could not be identified. The unsaturated phytosterols in position 5-6 were estimated to be negligible in the semipurified diet ( $<1$ p. 100) and undetected in the contents of the stomach and the small intestine. They were concentrated ( 3 p. 100) in the contents of the large intestine. When the digitonin complex broken down by pyridine was analyzed, and not the non-saponifiable fraction of the intestinal contents, the results were the same.

The quantities of sterols in the different digestive contents, isolated in animals sacrificed before the morning meal, are presented in table 1. The stomach contents contained approximately $80 \mathrm{mg}$ of sterols, the duodenum $40 \mathrm{mg}$, the proximal jejunum $400 \mathrm{mg}$ and the colic contents $950 \mathrm{mg}$.

Esterified sterols were practically non-existent in the small intestine. They accounted for 15 p. 100 of the total sterols in the stomach and cœcum (table 1). 
TABLE 1

Average mass of the intestinal contents $(\mathrm{g})$ and of the total $(\mathrm{T})$ and free $(\mathrm{F})$ sterols $(\mathrm{mg})$ in the intestinal contents of sows sacrificed before the first morning meal (8:30 a.m.)

\begin{tabular}{|c|c|c|c|c|}
\hline \multirow[b]{2}{*}{ Organ } & \multirow{2}{*}{$\begin{array}{l}\text { Intestinal } \\
\text { contents } \\
\text { (g) }\end{array}$} & \multicolumn{3}{|c|}{$\begin{array}{l}\text { Sterols from the contents } \\
\qquad(\mathrm{mg})\end{array}$} \\
\hline & & Total & Free & $\frac{\mathrm{F}}{\mathrm{T}} \times 100$ \\
\hline 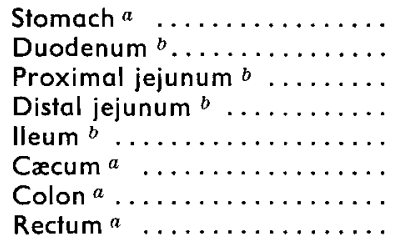 & $\begin{array}{r}376 \\
35 \pm 9 \\
322 \pm 87 \\
200 \pm 38 \\
28 \pm 10 \\
146 \\
1151 \\
470\end{array}$ & $\begin{array}{l}78 \\
38 \pm 7 \\
409 \pm 52 \\
72 \pm 17 \\
12 \pm 4 \\
67 \\
935 \\
188\end{array}$ & $\begin{array}{l}66 \\
35 \pm 7 \\
398 \pm 50 \\
72 \pm 17 \\
12 \pm 4 \\
55 \\
849 \\
174\end{array}$ & $\begin{array}{l}85 \\
92.1 \\
97.3 \\
100 \\
100 \\
82.1 \\
90.7 \\
92.5\end{array}$ \\
\hline
\end{tabular}

a Sows no. 9 and $10,{ }^{b}$ Mean results (t. SEM) for sows no. 5 to 10.

In the isolated walls of the digestive fract, free cholesterol concentration was constant : $2.3 \mathrm{mg} / \mathrm{g}$ from the duodenum to the ileum (sows no. 1 to 8 ) and $1.6 \mathrm{mg} / \mathrm{g}$ for the stomach and large intestine (sows no. 9 and 10) (table 2). The proportion of esterified cholesterol reached 3 p. 100 in the duodenum and 6 p. 100 in the proximal jejunum. On the other hand, it did not exceed 3 p. 100 in the stomach and the rest of the small intestine (cœecum,colon, rectum) if ranged from 4 to 5 p. 100 (table 2).

\section{TABLE 2}

Mean ( \pm SEM) moss $(\mathrm{g})$ of the intestinal walls, mean (-SEM) concentrations $(\mathrm{g} / \mathrm{kg}$ ) of free (F) and esterified $(E)$ cholesterol, and percentage of cholesterol in relation to total cholesterol $(F+E)$ in the various parts of the swine digestive tract

\begin{tabular}{|c|c|c|c|c|}
\hline \multirow{2}{*}{ Organ } & \multirow[b]{2}{*}{$\begin{array}{c}\text { Walls } \\
\text { (g) }\end{array}$} & \multicolumn{3}{|c|}{ Cholesterol } \\
\hline & & $\begin{array}{c}F \\
(g / k g)\end{array}$ & $\begin{array}{c}E \\
(g / \mathrm{kg})\end{array}$ & $\frac{F}{F+E} \times 100$ \\
\hline 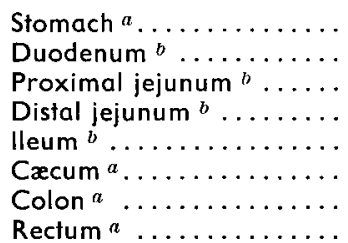 & $\begin{array}{c}467 \\
85 \pm 9 \\
409 \pm 66 \\
303 \pm 49 \\
71 \pm 3 \\
69 \\
634 \\
101\end{array}$ & $\begin{array}{l}1.75 \\
2.43 \pm 0.12 \\
2.42 \pm 0.08 \\
2.26 \pm 0.06 \\
2.30 \pm 0.09 \\
1.60 \\
1.56 \\
1.52\end{array}$ & $\begin{array}{l}0.04 \\
0.21 \pm 0.02 \\
0.16 \pm 0.02 \\
0.07 \pm 0.01 \\
0.06 \pm 0.01 \\
0.06 \\
0.08 \\
0.06\end{array}$ & $\begin{array}{l}97.8 \\
92.1 \pm 0.8 \\
93.8 \pm 0.7 \\
97.0 \pm 0.4 \\
97.7 \pm 0.4 \\
96.4 \\
95.1 \\
96.2\end{array}$ \\
\hline
\end{tabular}

a Sows no. 9 and $10,{ }^{b}$ Mean results ( \pm SEM) with sows no. 1 to 8. 
Cholesterol activity in the infestinal walls and contents and in the feces. - One hour after intake of the radioactive meal, a considerable quantity (25 p. 100) of cholesterol${ }^{14} \mathrm{C}$ was already present in the contents and the walls of the jejunum, at least in sow no. 1 . After $6 \mathrm{hrs}$, the cholesterol tracer attained the ileum (table 3). Whatever period of time elapsed (1,6 or $48 \mathrm{hrs}$ ) between intake of the labelled meal and sacrifice, the greatest part of the activity present in the small intestine was situated at the proximal jejunum level (table 3). Forty-eight hours after its intake, the dietary tracer was found in high amounts throughout the small intestine. Although, after 4 days, the activity of the contents in the proximal and distal jejunum was less than 0.4 p. 100 of the total activity ingested, the walls still contained 0.5 to 1 p. 100 (table 3 ).

\section{TABLE 3}

Activity (dpm) of the non-soponifiable fraction in the contents and adjacent walls of the small intestine, expressed as the percentage of activity ingested by 2 sows sacrificed $1 \mathrm{hr}, 6 \mathrm{hrs}, 48 \mathrm{hrs}$ or 96 hrs after a single ingestion of cholesterol-4-14 $\mathrm{C}(10 \mu \mathrm{Ci})$

\begin{tabular}{|c|c|c|c|c|c|c|c|c|c|}
\hline \multirow{2}{*}{$\begin{array}{l}\text { Duration } \\
(\mathrm{hr})\end{array}$} & \multirow{2}{*}{$\begin{array}{l}\text { Sow } \\
\text { No }\end{array}$} & \multicolumn{4}{|c|}{ Walls } & \multicolumn{4}{|c|}{ Contents } \\
\hline & & $\begin{array}{c}\text { Duode- } \\
\text { num }\end{array}$ & $\begin{array}{l}\text { Proximal } \\
\text { jejunum }\end{array}$ & $\begin{array}{c}\text { Distal } \\
\text { jejunum }\end{array}$ & Ileum & $\begin{array}{l}\text { Duode- } \\
\text { num }\end{array}$ & $\begin{array}{l}\text { Proximal } \\
\text { jejunum }\end{array}$ & $\begin{array}{c}\text { Distal } \\
\text { jejunum }\end{array}$ & Ileum \\
\hline 1 & $\begin{array}{l}1 \\
2\end{array}$ & $\begin{array}{l}0.87 \\
0.12\end{array}$ & $\begin{array}{r}10.32 \\
0.48\end{array}$ & $\begin{array}{l}0.02 \\
0.07\end{array}$ & $\begin{array}{l}0 \\
0\end{array}$ & $\begin{array}{l}0.57 \\
0.31\end{array}$ & $\begin{array}{r}14.82 \\
5.45\end{array}$ & $\begin{array}{l}0.26 \\
0.13\end{array}$ & $\begin{array}{l}0 \\
0\end{array}$ \\
\hline 6 & $\begin{array}{l}3 \\
4\end{array}$ & $\begin{array}{l}0.06 \\
0.07\end{array}$ & $\begin{array}{l}1.19 \\
2.94\end{array}$ & $\begin{array}{l}0.64 \\
0.30\end{array}$ & $\begin{array}{l}0.002 \\
0.003\end{array}$ & $\begin{array}{l}0.24 \\
0.15\end{array}$ & $\begin{array}{r}7.61 \\
16.74\end{array}$ & $\begin{array}{l}8.43 \\
0.16\end{array}$ & $\begin{array}{l}0.005 \\
0.15\end{array}$ \\
\hline 48 & $\begin{array}{l}5 \\
6\end{array}$ & $\begin{array}{l}0.44 \\
0.64\end{array}$ & $\begin{array}{l}9.49 \\
5.05\end{array}$ & $\begin{array}{l}1.20 \\
1.29\end{array}$ & $\begin{array}{l}0.07 \\
0.12\end{array}$ & $\begin{array}{l}0.18 \\
0.13\end{array}$ & $\begin{array}{l}9.13 \\
9.22\end{array}$ & $\begin{array}{l}0.15 \\
0.76\end{array}$ & $\begin{array}{l}0.009 \\
0.26\end{array}$ \\
\hline 96 & $\begin{array}{l}7 \\
8\end{array}$ & $\begin{array}{l}0.11 \\
0.10\end{array}$ & $\begin{array}{l}0.50 \\
0.81\end{array}$ & $\begin{array}{l}0.82 \\
0.80\end{array}$ & $\begin{array}{l}0.05 \\
0.03\end{array}$ & $\begin{array}{l}0.05 \\
0.04\end{array}$ & $\begin{array}{l}0.29 \\
0.35\end{array}$ & $\begin{array}{l}0.28 \\
0.17\end{array}$ & $\begin{array}{l}0.02 \\
0.01\end{array}$ \\
\hline
\end{tabular}

The activity of fecal neutral sterols was measured (sows no. 5 to 10) from day 1 of the experiment. No activity was discerned in the stools of 6 sows during the first 3 days. In 3 out of 4 cases (sows no. 7, 8 and 9), fecal elimination of unabsorbed cholesterol began on day 4 ; in sow no. 10 , it began on day 6 . The mean cholesterol transit time was therefore at least 4 days for the swine living under our experimental conditions. The pattern in time of fecal neutral sterol activity in sows no. 9 and 10 is given in figure 1.

Specific cholesterol activity in plasma and in intestinal walls and contents. - The specific activity of free cholesterol in plasma and red blood cells and of esterified cholesterol in plasma only became almost equal after 4 days (fig. 2). The mean specific activity of plasma free cholesterol was measured during the 33 days following intake of a single meal labelled with cholesterol-4-14C. This pattern was observed for 150 days 

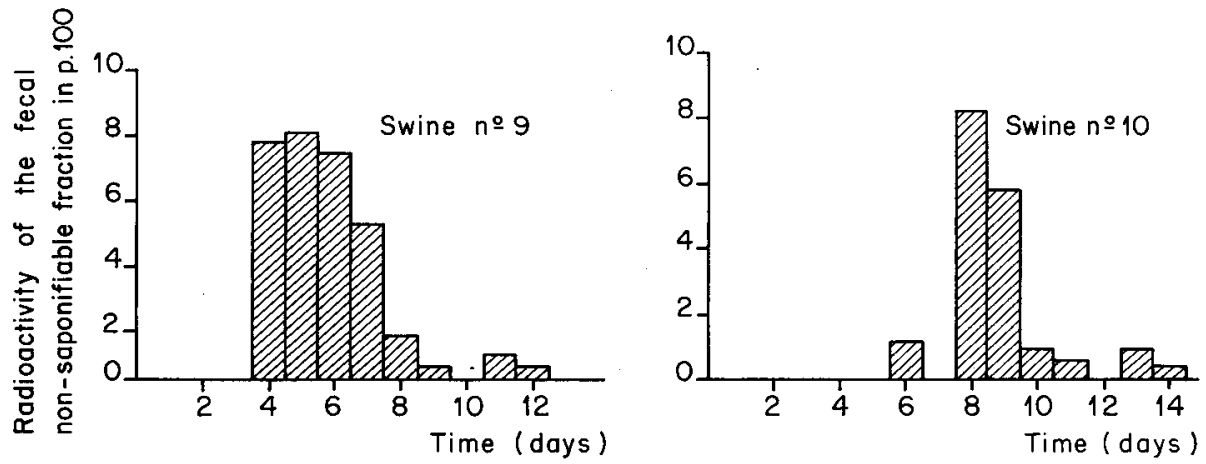

FIG. 1. - Activity of the non-saponifiable fraction of feces collected daily after intake of cholesterol-4-14C incorporated into the meal (in percentage of ingested cholesterol activity : $10 \mu \mathrm{Ci}$ ).

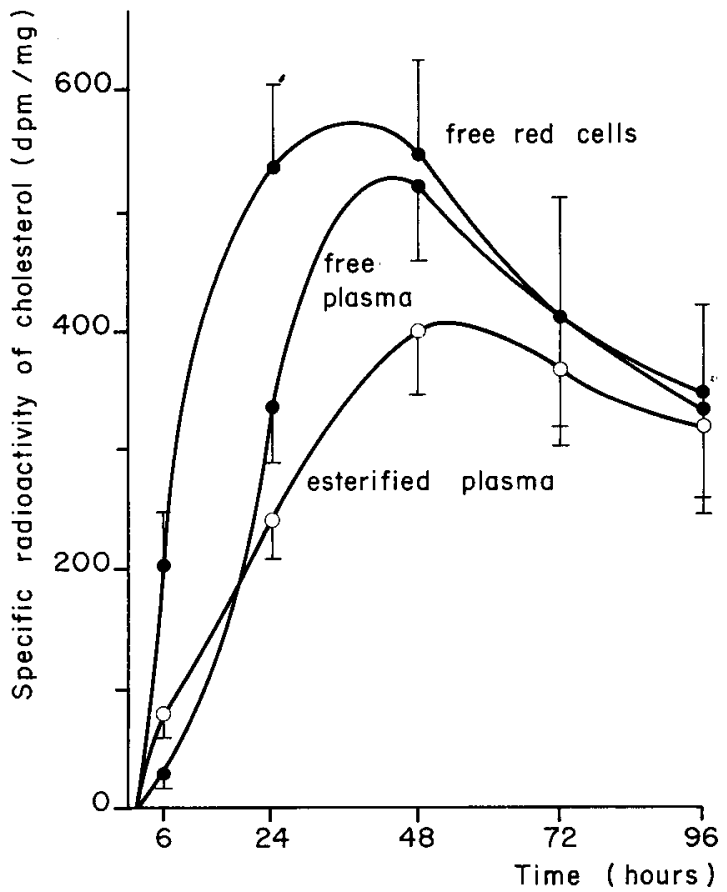

FIG. 2. - Time course (in hrs) of specific cholesterol activity (dpm/mg) \pm SEM in plasma and red blood cells of sows no. 1 to 8 after a single intake of cholesterol-4-14 $\mathrm{C}(10 \mu \mathrm{Ci})$ incorporated into the meal.

after intravenous injection of a red blood cell suspension of the tracer (fig. 3). If, in these two experiments, the mean specific activity of plasma free cholesterol is expressed as a percentage of the specific activity of the plasma free cholesterol measured on day 6 , it is observed that the time curves of these relative values are identical (fig. 4). 


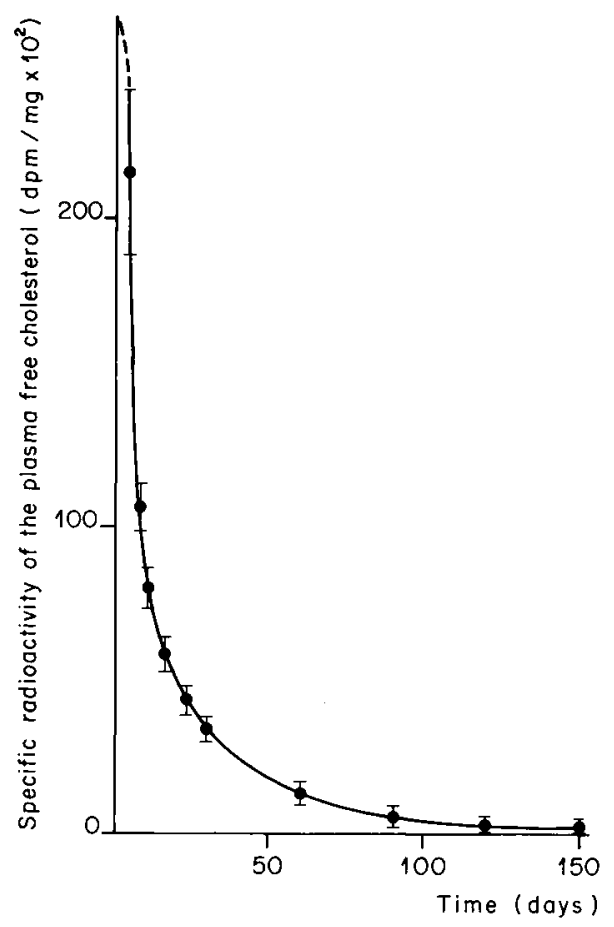

FIG. 3. - Time course (in days) of specific free cholesterol activity ( $\mathrm{dpm} / \mathrm{mg}) \pm \operatorname{SEM}$ (4 sows) ni plasma after $a$ single intravenous injection of a red blood cell suspension of tritiated cholesterol $(400 \mu \mathrm{Ci})$.

One hour after a single intake of the meal tracer, the intestinal wall contained free labelled cholesterol (with the exception of the ileum) and esterified labelled cholesterol (with the exception of the distal jejunum and ileum) (table 4). Specific free cholesterol activity in the proximal jejunum wall was always higher than that of the free cholesterol in the other segments (table 4). With one exception (sow no. 5, table 4), this was also

\section{TABLE 4}

Specific activities $(\mathrm{dpm} / \mathrm{mg})$ of free $(\mathrm{F})$ and esterified $(\mathrm{E})$ cholesterol of the small intestine wall in 2 sows sacrificed $1 \mathrm{hr}, 6 \mathrm{hrs}, 48 \mathrm{hrs}$ or 96 hrs ofter a single ingestion of cholesferol-4-14 C $(10 \mu \mathrm{Ci})$

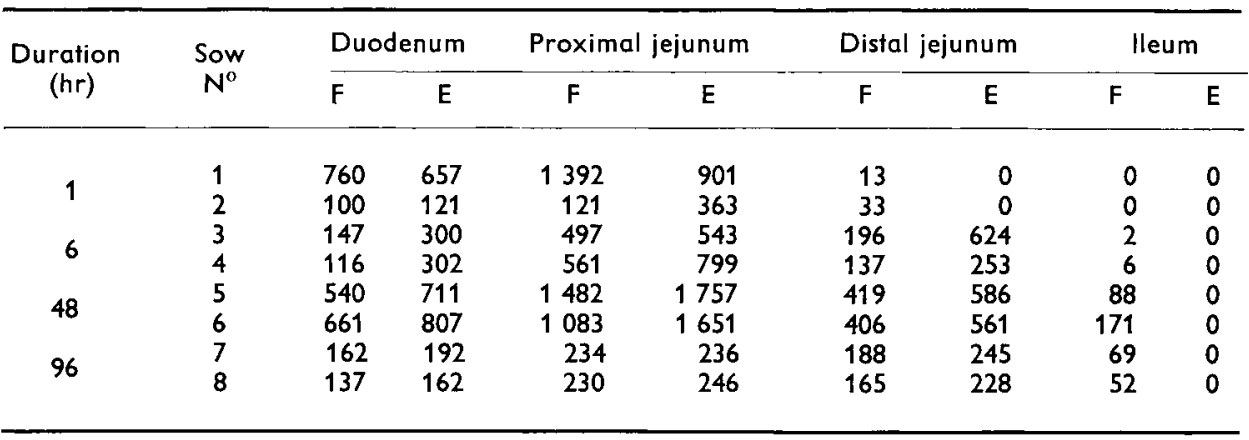


the case for esterified cholesterol. Moreover, the specific activity of the total cholesterol in the proximal jejunal contents was always higher than the specific activity of the total cholesterol in the other intestinal contents (fable 5).

TABLE 5

Specific cholesterol activity $(\mathrm{dpm} / \mathrm{mg})$ in the small intestine contents of 2 sows sacrificed $1 \mathrm{hr}, 6 \mathrm{hrs}, 48 \mathrm{hrs}$ or $96 \mathrm{hrs}$ ofter a single intake of cholesterol-4- ${ }^{14} \mathrm{C}(10 \mu \mathrm{Ci})$.

\begin{tabular}{cccccr}
\hline $\begin{array}{c}\text { Duration } \\
\text { (hr) }\end{array}$ & $\begin{array}{c}\text { Sow } \\
\text { No }\end{array}$ & Duodenum * & $\begin{array}{c}\text { Proximal * } \\
\text { jejunum }\end{array}$ & $\begin{array}{c}\text { Distal } \\
\text { jejunum }\end{array}$ & Ileum \\
\hline & 1 & 3329 & 5874 & 904 & 0 \\
1 & 2 & 630 & 1400 & 146 & 0 \\
& 3 & 6088 & 7573 & 7286 & 240 \\
6 & 4 & 2746 & 8419 & 4976 & 8021 \\
& 5 & 722 & 2729 & 469 & 637 \\
& 6 & 875 & 2956 & 920 & 1464 \\
96 & 7 & 293 & 311 & 447 & 539 \\
& 8 & 278 & 327 & 497 & 677 \\
\hline
\end{tabular}

* Paired t-test, statistically significant difference at $P<0.05$.

Value of the absorption coefficient. - The experiments on labelled cholesterol intake were not carried out long enough (33 days) to determine accurately the total integral specific activity of plasma free cholesterol, $a(I)$, from zero to infinity. So, as the relative decay of this specific activity, $a(l)$, was identical after 6 days to that of the specific activity of plasma free cholesterol, $a(x)$, obtained after an intravenous injection of a red blood cell suspension of the tracer (monitored for 150 days) (fig. 4), we assumed that

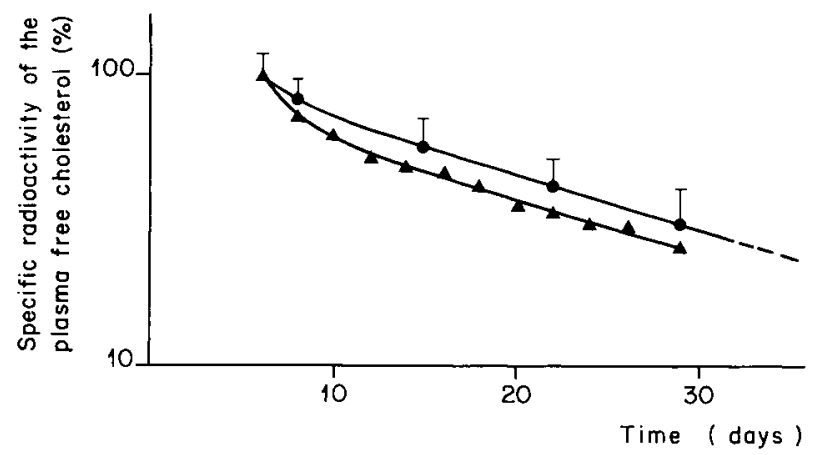

FIG. 4. - Time course (in days) of mean specific activity of plasma free cholesterol expressed as a percentage of the specific activity of plasma free cholesterol on experimental day 6.

$\mathrm{T} \pm$ SEM for the 4 sows given a single intravenous injection of a red blood cell suspension of tritiated labelled cholesterol $(400 \mu \mathrm{Ci})$. \& Mean value of 2 sows (no. 9 and 10) which ingested $10 \mu \mathrm{Ci}$ of cholesterol-4. ${ }^{14} \mathrm{C}$ incorporated into the meal. The individual values do not deviate more than 10 p. 100 from the mean value. 
the final slope of the decay curves from 33 to 150 days was the same in the two experiments, and we could thus extrapolate those curves to infinity. The values for the areas, $\int_{0}^{\infty} a(l)$ and $\int_{0}^{\infty} a(x)$, under the decay curves taken to infinity, were determined graphically. This gave : $\int_{0}^{\infty} a(l)=8290 \mathrm{dpm} / \mathrm{mg}$ for $\mathrm{q}(\mathrm{l})=10 \mu \mathrm{Ci}$ and $\int_{0}^{\infty} \mathrm{a}(\mathrm{x})=$ $580000 \mathrm{dpm} / \mathrm{mg}$ for $\mathrm{q}(\mathrm{x})=400 \mu \mathrm{Ci}$. The mean absorption coefficient of swine living under our experimental conditions was therefore $57 \pm 4$ p. 100 .

\section{Discussion.}

Cholesterol was the major sterol ( 99 p. 100) present in the contents of the stomach and the small intestine. However, coprostanol was not detected, thus showing that swine are not coprophagic. The bacterial transformation of cholesterol into coprostanol began in the cecum and remained weak in the colon and rectum; the percentages of transformed cholesterol are 4.5 and 6 p. 100, respectively. Therefore, the cholesterolreducing capacities of the bacterial flora, under our experimental diefary conditions, were considerably weaker than those normally encountered in rat (Lutton and Chevallier, 1972) or man (Ferezou et al.. 1978).

Before the morning meal, the stomach and the small intestine contained 78 and $531 \mathrm{mg}$ cholesterol, respectively (table 1). The latter value, which is much higher than the quantity $(40 \mathrm{mg})$ of cholesterol ingested during a meal, corroborates the endogenous origin of the cholesterol in the intestinal contents. In rats, the linear concentration of cholesterol in the digestive tract (quantity of cholesterol contained in $1 \mathrm{~cm}$ of infestine) increases exponentially from the pylorus to the cecal extremity of the intestine (Chevallier and Lutton, 1972 ; Mclntyre et al., 1971). Such a distribution does not exist in swine, as the linear sterol concentration is six times greater in the proximal than in the distal jejunum (table 1). This conclusion is valid as the length of the two segments of the jejunum is about the same.

Fifteen percent of the cholesterol is esterified in the stomach contents. This percentage in the small intestine decreases as the alimentary bolus progresses to become zero in the distal jejunum and ileum. Another esterification occurs in the cecum. These results confirm that hydrolysis surpasses esterification in the small intestine, as in rats (Chevallier and Vyas, 1963 ; Treadwell and Vahouny, 1968).

Several remarks are in order concerning the isotopic results on cholesterol in the intestinal contents.

1) The dietary cholesterol ingested has a specific activity of $555000 \mathrm{dpm} / \mathrm{mg}(40 \mathrm{mg}$, $10 \mu \mathrm{Ci}$ ). As the sows ingested the meal in less than $10 \mathrm{~min}$, we calculated specific cholesterol activity from the stomach contents, taking into account that dietary cholesterol was diluted by the $78 \mathrm{mg}$ present in those contents before the morning meal (table 1). The dietary cholesterol then penetrated into the duodenum where it was again diluted by the cholesterol $(38 \mathrm{mg}$ ) of the duodenal contents (table 1). One hour after intake of the tracer (cholesterol-4-14 $\mathrm{C}$ ) meal, specific cholesterol activity in the duodenal contents was $3329 \mathrm{dpm} / \mathrm{mg}$ for sow no. 1 and $630 \mathrm{dpm} / \mathrm{mg}$ for sow no. 2 (table 5). These very weak specific cholesterol activities in the duodenum could result from minimal quanti- 
ties of the meal which crossed the pylorus. However, this interpretation would not be valid since 6 hrs after the tracer meal was ingested, and at least 90 p. 100 of it had passed from the stomach into the intestine (Laplace and Tomassone, 1970), specific cholesterol activities in the duodenum reached 6088 and $2756 \mathrm{dpm} / \mathrm{mg}$ (sows no. 3 and 4 , table 5). These values, which are much lower than the specific activity of the dietary cholesterol, show that the endogenous cholesterol in the digestive tract is renewed rapidly. The ratio of the specific activity of cholesterol in the duodenal contents to that of dietary cholesterol implies that the corresponding flows were diluted by a factor of 50 to 100 , as in rats (Chevallier and Lutton, 1972).

2) Whatever the experimental time ( $1 \mathrm{hr}, 6 \mathrm{hrs}, 2$ days, 4 days) after intake of the tracer meal, specific cholesterol activity in the proximal jejunum contents was always higher than that measured in the duodenum (paired t-test ; table 5), showing that the dietary cholesterol ratios are higher in the contents of the proximal jejunum than in those of the duodenum. Thus, the cholesterol from the stomach does not form an homogeneous mixture with the endogenous cholesterol of the intestinal contents. In rats, the intestinal cholesterol is distributed in two compartments : the first comprises cholesterol originating in the stomach and the second, endogenous cholesterol. The latter compartment only contains endogenous cholesterol in an exchange relationship with the intestinal mucosa (Chevallier and Lutton, 1972). It is evident that we cannot accurately analyze cholesterol movements in the intestinal contents of swine. However, the above observations show that the organization of the intestinal contents of these animals is similar to that described in rats, and that the fate, particularly the biliary fate, of the endogenous choiesterol, is probably not the same as that of exogenous cho" lesterol, as shown in rats (Lutton and Brot-Laroche, 1979).

3) Several other points concerning the rate and localization of internal dietary cholesterol absorption in swine are indicated in table 3. Six to 15 p. 100 of the cholesterol ingested was already present in the duodenum and jejunal walls $1 \mathrm{hr}$ after the tacer meal had been ingested, demonstrating that gastric evacuation began quickly. This evacuation occurs discontinuously by successive spurts interrupted by watering (Laplace, 1975). However, 48 hrs after intake of the tracer meal, at least 10 p. 100 of the ingested cholesterol radioactivity was still present in the small intestine, and $9 / 10$ in the proximal jejunum. This tracer cholesterol could not be absorbed cholesterol, discharged into the plasma and then excreted into the lumen since, at experimental hour 48 , the specific cholesterol activity in the wall of the proximal jejunum (table 4) was approximately 3 times greater than the specific cholesterol activity in blood (fig. 2). Specific cholesterol activity in the contents of the proximal jejunum (table 5 ) is equal to a factor of about 6. Hence, the transit of diefary cholesterol in the small intestine lumen was slow in our experimental animals as the jejunal dietary bolus is normally emptied 6 to $10 \mathrm{hrs}$ after a meal has been ingested (Gürtler, 1965) and, consequently, the transfer of the dietary cholesterol tracer from the intestinal lumen to the plasma took longer in our swine than in other species. Indeed, in rat as in man, the peak of the tracer wave in the intestinal wall or the blood is reached 10 to $12 \mathrm{hrs}$ after intake of a meal containing labelled cholesterol (our unpublished data). Figure 2 shows that, as in the case of the intestinal wall (table 4), the specific activity of the plasma free or esterified cholesterol and of red blood cell free cholesterol was maximal 48 hrs after intake of the tracer 
meal. Moreover, after cholesterol-4-14C was introduced directly into the duodenal lumen of miniature swine, Dupont ef al. (1974) noted that the activity peak of the serum was situated at about $32 \mathrm{hrs}$. Finally, in young Yorkshire swine, ingesting an hypercholesterolemia-inducing diet (0.38 p. 100), and then treated with cholestryamine, this activity peak was reached 48 hrs after ingestion of a meal labelled with cholesterol-4${ }^{14} \mathrm{C}$ (Kim et al., 1975). On the other hand, this time was reduced to $24 \mathrm{hrs}$ when the swine were treated with clofibrate (Kim ef al., 1975). Considering all these data, it can be inferred that the processes of cholesterol dynamics in the small intestine contents of our swine were slower than in other species. One of the factors responsible for this is most certainly the nature of the diet we used, a semi-purified diet containing only 4 p. 100 fiber (cellulose). However, this is not the only factor implicated, as the results of the other authors were obtained with animals eating a commercial diet containing more fiber than our purified diet.

4) Finally, although the presence of labelled cholesterol in the walls of the duodenum, jejunum and ileum shows that there is dietary cholesterol absorption throughout the small intestine, the activity rate of the ingested cholesterol, representing 60 to $80 \mathrm{p}$. 100 of the activity in the entire small intestine wall, is highest in the proximal jejunum up to $48 \mathrm{hrs}$ (table 3 ) ; the dietary cholesterol therefore seems to be absorbed preferentially in the first-half of the small intestine. This situation is similar to that described in man (Treadwell and Vahouny, 1968) but different than the case in rat (Chevallier and Lutton, 1972).

The absorption coefficient (57 \pm 4 p. 100) measured in our experimental animals, using the principle of occupancy of every dynamic system in equilibrium, is, on the one hand, close to that (41.5 p. 100) measured by Dupont et al. (1974) according to the method of Zilversmit (1972) - a modification of the method of Shimmins et al. (1969) used by us - and, on the other hand, to the absorption coefficient (56.5 p. 100) measured by the balance method used in 3 Yorkshire swine of $20 \mathrm{~kg}$ treated or not with clofibrate (Kim ef al., 1974) and fed a hypercholesterolemia-inducing (0.38 p. 100) diet. Moreover, other authors (again using a balance method with 4 swine of the same stock but weighing $40 \mathrm{~kg}$ ) found an absorption coefficient of $25.5 \mathrm{p} .100$ with a hyperlipid milk diet and of 4.7 p. 100 with a hypolipid commercial diet. In both cases, cholesterol concentration was 0.38 p. 100 (Marsh et al., 1972). In addition, these authors again found 95 p. 100 of the $\beta$-sitosterol ingested by the animal in the stools. Nevertheless, they concluded that there was a notable cholesterol degradation during intestinal transit. It may be pointed out that, if such a degradation occurs, the value of the absorption coefficient calculated by our method would not be modified, as it is not the same with the balance method.

Reçu en novembre 1980. Accepté en février 1981.

Acknowledgements. - We are most grateful to Dr. P. A. Villiers for his technical assistance (bleeding and dissection of the sows) and to Mr. F. Dacher for animal care.

Résumé. La nature et la répartition des stérols neutres ont été déterminées dans le tractus digestif de porcs femelles adultes Large White maintenus dans un équilibre biologique défini (poids constant $70 \pm 5 \mathrm{~kg}$ ). L'alimentation est semi-synthétique et contient 0,08 p. 100 
de cholestérol. Le cholestérol est le stérol majeur des contenus intestinaux du tractus digestif. II est partiellement transformé en coprostanol ( \pm 6 p. 100) à partir du cæcum. Juste avant le repas du matin, les contenus du tube digestif du porc sont riches en cholestérol $(532 \mathrm{mg}$ dans l'intestin grêle). Comme chez le rat, ce cholestérol, d'origine endogène, rapidement renouvelé, ne se répartit pas de manière homogène avec le cholestérol exogène (i.e. alimentaire). Enfin, au cours du transit intstinal du cholestérol, c'est l'activité hydrolysante qui l'emporte sur l'activité estérifiante.

La mesure du coefficient d'absorption, par la propriété d'occupation de tout système dynamique, a nécessité deux expériences isotopiques : une ingestion unique de cholestérol${ }_{4-14} \mathrm{C}(10 \mu \mathrm{Ci})$, incorporée au repas ef une injection intraveineuse unique de cholestérol-- ${ }^{3} \mathrm{H}$ $(400 \mu \mathrm{Ci})$ sous la forme d'une suspension d'hématies autologues préalablement marquées in vitro. Ainsi déterminé, le coefficient d'absorption du cholestérol alimentaire atteint, dans nos conditions expérimentales, 57 p. 100. Il est absorbé principalement dans la première moitié de l'intestin grêle comme chez l'homme, alors que chez le rat, il l'est dans la seconde moitié. Ce cholestérol alimentaire marqué apparaît plus tardivement dans la circulation générale du porc que dans celle du rat ou de l'homme, puisque après l'ingestion d'un repas dont le cholestérol est marqué, le maximum de la radioactivité du cholestérol plasmatique est atteint après $48 \mathrm{~h}$ chez le premier alors qu'il l'est après 10-12 h chez les seconds.

\section{References}

AIGUEPERSE J., 1980. Le système cholestérol du port. Rapport CEA-R 5039.

AIGUEPERSE J., REMY J., CHEVALLIER F., 1978. Sterols in various organs of adulf female swine. Ann. Biol. anim. Bioch. Biophys., 18, 1317-1324.

AIGUEPERSE J., LUTTON C., CHEVALLIER F., 1981a. Identification and origins of neutral fecal sterols in adult Large Whife sows : occurrence of externally-secreted intestinal cholesterol. Reprod. Nutr. Dévelop., 21, 545-554.

AIGUEPERSE J., CHEVALLIER F., 1981b. In vivo study of cholesterol turnover in the blood (red cells and plasmatic lipoproteins) of adult female swine (in preparation).

BERGNER P. E. E., 1964. Tracer dynamics and the determination of pool sizes and furnover factors in metabolic systems. J. theor. Biol., 6, 137-158.

CAMINADE R., 1922. Sur quelques modifications apportées au dosage de la cholestérine par la méthode de Windaus. Bull. Soc. Chim. biol., 4, 601-613.

CHEVALLIER F., 1972. Biodynamique ef indicateurs. Gordon and Breach Sci. Publ. N. Y. London, Paris.

CHEVALLIER F., LUTTON C., 1972. Mouvements des stérols dans le tube digestif d'un rat. Absorption du cholestérol de synthèse. Biochim. biophys. Acto, 274, 382-411.

CHEVALLIER F., MATHÉ D., 1964. Destinée du cholestérol des chylomicrons chez le rat. III. Mouvements de cholestérol-4-14 $\mathrm{C}$ entre les chylomicrons et la lymphe ou le sérum in vivo. Bull. Soc. Chim. biol., 46, 509-527.

CHEVALLIER F., VYAS M., 1963. Les origines du cholestérol du chyle. Bull. Soc. Chim. biol., 44, 253276.

DUPONT J., OH S. Y., O'DEEN L., MC CLELLAN M. A., LUMB W. V., BUTTERFIELD A. B., CLOW D. J., 1974. Cholesterol and bile acid turnover in miniature swine. Lipids, 9, 717-721.

FEREZOU J., GOUFFIER E., COSTE T., CHEVALLIER F., 1978. Daily elimination of fecal neutral sterols by humans. Digestion, 18, 201-212.

GÜRTLER H., 1965. Physiologie des animaux domestiques. In E. KOLB, VIl. — Physiologie de la digestion et de l'absorption, Vigot Frères, Paris, 296 Pp.

McINTYRE N., KIRSCH K., ORR J. C., ISSELBACHER K. L., 1971. Sterols in the small intestine of rats, guinea pig and rabbit. J. Lipid Res., 12, 336-346.

KAMMERECK R., WEN-MUI L., PALIOKAS A., SCHROEFFER G. J., 1967. Thin layer chromatography of sterols on neutral alumina impregnated of silver nitrate. J. Lipid Res., 8, 282-283.

KIM D. N., LEE K. T., REINER J. M., THOMAS W. A., 1974. Restraint of cholesterol accumulation in tissue pools associated with short-term lowering of serum cholesterol levels by clofibrate or cholestyramine in hypercholesterolemic swine. J. Lipid Res., 15, 326-331. 
KIM D. N., LEE K. T., REINER J. M., THOMAS W. A., 1975. An evaluation of some of the potential immediate sources of cholesterol for bile acid synthesis in swine. Exp. Mol. Path., 22, 284-293.

LAPLACE J. P., 1975. Le transit digestif chez les monogastriques. II. - Phénomènes moteurs et mouvement des digesfa. Ann. Zootech., 24, 489-522.

LAPLACE J. P., TOMASSONE R., 1970. Evacuation gastro-duodénale chez le porc. Fistulisation chronique par voie thoracique extrapleurale; recherche d'une technique d'analyse mathématique de l'évacuation. Ann. Zootech., 19, 303-332.

LUTTON C., CHEVALLIER F., 1972. Analyse des stérals des contenus digestifs ef des fèces du rat. Biochim. biophys. Acla, 260, 133-145.

LUTTON C., BROT-LAROCHE E., 1979. Biliary cholesterol absorption in normal and L-thyroxin fed rats. Lipids, 14, 441-446.

MARSH A., KIM D. N., LEE K. T., REINER J. M., THOMAS W. A., 1972. Effect of combined clofibratecholestyramine treatment on serum and tissue cholesterol pools and on cholesterol synthesis in hypercholesterolemic swine. J. Lipid Res., 13, 600-615.

ORR J. S., GILLESPIE F. C., 1968 . Occupancy principle for radioactive tracers in steady biological systems. Science, 162, 138-139.

SCHOENHEIMER R., DAM H., 1953. Uber die Spaltbarkeit und Löslichkeit von Sterindigitoniden. Hoppe Seyler Z., 215, 59-63.

SHIMMINS J., GILLESPIE F. C., ORR J. S., SMITH D. A., ALEXANDER N. D., 1969. The measurement of enteric absorption rate using a double tracer technique. In RASOE G., Advances in Biosciences, 5, 157-163. Pergamon Press.

TREADWELL C. R., VAHOUNY G. V., 1968. In Handbook of physiology. CODE C. F., Sect. 6, Alimentary canal, vol. 3, 1407-1438, Am. Physiol. Soc., Washington.

ZILVERSMIT D. B., 1972. A single blood sample dual isotope method for the measurement of cholesterol absorption in rat. Proc. Soc. exp. Biol. Med., 140, 862-865. 